\title{
Teaching English Speaking Online versus Face-to-Face: Saudi Students' Experience during the COVID-19 Pandemic
}

\author{
Abdulrahman Alzamil \\ Department of Foreign Languages \\ Taif University, Saudi Arabia \\ Email:dr.aa.alzamil@gmail.com
}

Received: $12 / 14 / 2020$

Acceoted: $2 / 25 / 2021$

Published:3/24/2021

\begin{abstract}
In March 2020, schools in the Kingdom of Saudi Arabia were suspended. Online learning became a substitute for traditional face-to-face learning. This study addresses the implications of this shift for the attitudes of university-level English majored Saudi students taking a listening and speaking course. The study investigated the students' attitudes towards: a) the importance of speaking in English; b) teachers use of emails to communicate their feedback on students' English-speaking tasks; c) online teaching of English speaking; and d) online learning and teaching of the English language. The data collection tool was a 21-item questionnaire. The participants were 18 second-year male Saudi students who were studying English at a Saudi university. The findings showed that the participants: a) had positive attitudes towards the importance of speaking English; b) appreciated the benefits that online learning offers, but felt it could not replace face-to-face learning.

Keywords: COVID-19 pandemic, face-to-face learning, online learning, Saudi EFL students, teaching speaking

Cite as: Alzamil, A. (2021).Teaching English Speaking Online versus Face-to-Face: Saudi Students' Experience during the COVID-19 Pandemic. Arab World English Journal, 12 (1) 1927. DOI: https://dx.doi.org/10.24093/awej/vol12no1.2
\end{abstract}




\section{Introduction}

Of the four skills in English (reading, writing, listening and speaking), mastering speaking is a priority for most L2 learners. Saudi students learning English are no exception, and are aware of the importance of expressing themselves fluently in English. Since the world was hit by the COVID-19 pandemic in December 2019, the shape of learning and teaching has changed tremendously. Face-to-face learning was replaced by online learning in many parts of the world (Fansury, Januarty, \& Rahman, 2020). Saudi Arabia suspended all schools and educational institutes in March 2020, replacing it with implemented online and distant learning for the duration of the suspension, thus altering the form of communication between teachers and students.

This study investigates students' attitudes towards the shift from face-to-face learning to online learning in a Saudi university English department and whether this facilitates or hinders their ability to master L2 speaking. Examining this provides us with greater insight into: a) the online learning approach; b) its consequences for teaching and evaluating speaking skills; and c) students' views on speaking in a virtual class versus speaking in an actual class. The study aims to answer the following research questions:

1. What attitudes do university-level Saudi students who specialise in English have towards:

a. the importance of speaking in English;

a. teachers' use of emails in communicating their feedback for students' Englishspeaking tasks;

b. online learning of English speaking; and

c. online learning of the English language?

\section{Literature Review}

\section{Teaching English in Saudi Arabia}

According to Alhmadi (2014), the Saudi education system consists of three levels: a) primary (six years); b) intermediate (three years); and secondary (three years). The school year consists of two fifteen-week semesters. Students start learning English in the fourth year of the primary level. Students have four classes (45 minutes each) of English a week. Alhmadi (2014) has asserted that school students graduate with low levels of English proficiency because they do not get adequate exposure to the English language at secondary school. As a result, students who specialise in English at university-level struggle with English, especially at the beginning.

\section{Teaching L2 English Speaking}

Speaking is a means of expressing meaning in speech (Alsaedi, 2012; Fulcher, 2003). Speaking in L1 and L2 is a productive skill that is acquired unconsciously in L1 and consciously in L2. Conversely, writing and reading are learned consciously in both L1 and L2 (Sharma, 2015), and are learned later in life because they are skills that need to be taught.

In his investigation of factors affecting Saudi undergraduate students' speaking skills, Hamad (2013) enrolled 150 female students, who then completed a questionnaire. He found that the main obstacle to speaking English was the students' fear of speaking it, even in more private conditions such as making a phone call. The students attributed this to a lack of opportunities to 
speak English and to strategies implemented by their teachers, who focused more on improving their listening skills than their speaking skills. This is supported by Alharbi (2015) who stated that practicing English in authentic situations is difficult in EFL contexts such as Saudi Arabia. Another possibility is that the focus in education institutions is on improving writing skills, as supported by study outlined below.

Drawing on a sample of 90 students and 10 teachers, Al-Ahdal, Alfallaj, Al-Awaied, \& Al-Hattami (2014) examined Saudi students' L2 speaking and writing skills. Data was collected using a mixture of questionnaires, interviews and tests to compare both skills. It was found that participants' writing skills were better than their speaking skills. The authors suggested that teachers should cooperate with students and their parents to create a suitable environment for them to practise speaking in English.

Another study was conducted by Ali, Shamsan, Guduru, \& Yemmela (2019) with 100 Saudi undergraduates (50 males and 50 females) to investigate their attitudes towards Englishspeaking skills. A questionnaire was administered, and the findings revealed that both male and female students had the same positive attitudes towards speaking in English, and that it is a crucial skill.

It can be observed from the studies above that speaking in English is difficult for L2 learners of English and that this is an issue for both males and females. The reasons vary from not focusing enough on improving students' speaking skills to other factors related to the learning environment and practicing speaking. The next section discusses the teaching of L2 speaking in an online learning environment.

\section{Online Learning}

Online or electronic learning (E-learning) has become an important aspect of the provision of education materials around the world. However, the extent to which it is used differs from place to place (Harandi, 2015). Using email in communication and E-books in teaching have become common practices in the vast majority of universities around the world (Harandi, 2015). However, technology has yet to replace the traditional teacher-classroom-student form of teaching. Saudi universities started to adopt online learning in their teaching plans by establishing institutes and colleges to work on transforming the form of learning (Al-Asmari \& Khan, 2014), and implementing online learning has been the focus of the Saudi Ministry of Education since 2005 (Alhabeeb \& Rowley, 2017). A number of studies have addressed the effectiveness of online learning and asked whether students prefer it to face-to-face learning. Three such studies are discussed below.

Paechter and Maier's (2010) study aimed to investigate students' attitudes towards online learning vs. face-to-face learning. They recruited 2196 Austrian undergraduates, whose opinions were collected by means of a questionnaire. Their results show that participants thought online learning was a clear and more organised approach to learning. They also preferred face-to-face learning when communication was required.

Gorra and Bhati (2016) examined the consequences of online learning for university-level students in the Philippines. Based on a sample of 221 students, the study used a questionnaire to 
seek their opinions about the importance of online learning. They found that the students had positive attitudes to the use of technology in learning, and that it had positive effects on the learning experience. However, students had negative attitudes towards the use of social media in learning, as students may use social media to chat and play music and games, which may have negative consequences on learning outcomes.

A recent study carried out by Fansury et al. (2020) examined the effects of the COVID-19 pandemic on learning. Interview data were collected from 50 students and 20 teachers in Indonesia, who were also asked to complete a questionnaire. The results showed that learning can take place digitally to overcome social distancing and the suspension of schools. Moreover, they found that students preferred online learning to traditional classroom learning. Nevertheless, both teachers and students complained about technical problems such as internet disconnection and the cost of internet data.

The online learning studies discussed above show that both students and teachers view online learning positively. However, it is not clear whether students prefer it simply because they are bored with traditional methods and it is a new form of teaching, or whether they like it because it is actually more effective

\section{Methods}

To minimise bias and facilitate generalisation of the data (Larson-Hall, 2016), this study took a quantitative approach to data collection. There were 18 participants (mean age 20.5 years; $\mathrm{SD}=1.1$ ) who were all second-year university-level students studying English at a Saudi university. There were intended to be 29 participants, but due to difficulty in reaching some students only 18 were recruited.

All participants were taking Listening and Speaking II (in addition to other courses). Given that the Saudi ministry of education suspended schools and universities on the $8^{\text {th }}$ of March, participants attended eight weeks of traditional learning and about seven weeks of online learning. As part of the evaluation of their speaking skills in Listening and Speaking II, they were asked to give presentations roughly 2-5 minutes long. They were notified of each presentation topic one week in advance to give them time to prepare, and each student gave a total of eight presentations distributed throughout the semester (six face-to-face and two online presentations). The students had to stand in front of their classmates to deliver their presentations face-to-face, but to avoid any psychological pressure their teachers' comments were provided to each student privately, and not in front of their classmates. The online presentations had to be recorded using a camera, and students were asked to stand during their delivery and pretend to be in a real classroom. The resulting videos were then sent to the teacher by email for assessment, with teachers' comments on student presentations also sent by email.

Like previous studies that have examined online learning vs. face-to-face learning (e.g., Fansury et al., 2020; Hamad, 2013; Paechter \& Maier, 2010), this study used a questionnaire to collect the data. Students were asked closed-ended questions, and had to choose their answer from a 5-point Likert scale in which the responses ranged from strongly disagree to disagree, uncertain, agree and strongly agree. The 21-item questionnaire consisted of four constructs designed to seek their attitudes towards: a) the importance of speaking in English; b) teachers' 
use of email to communicate their feedback on students' English-speaking tasks; c) online teaching of English speaking; and d) online learning and teaching of the English language. The goal of the questionnaire was explained to the participants before it was administered. Because of the coronavirus pandemic, the questionnaire was administered online.

\section{Results}

This section reports the results of the four parts and each part addresses one of the four questionnaire constructs. The participants' responses are shown as numbers (frequency) and percentage scores.

Table 1. Descriptive statistics for the importance of speaking in English

Questionnaire item $\begin{aligned} & \text { Strongly } \\ & \text { disagree }\end{aligned}$ Disagree $\begin{array}{l}\text { Uncertai } \\ \mathrm{n}\end{array}^{\text {Agree }} \begin{aligned} & \text { Strongly } \\ & \text { agree }\end{aligned}$

\begin{tabular}{lrllll}
\hline 1. It is important to master speaking skills in0 & 0 & 0 & 10 & 8 \\
English. & $0 \%$ & $0 \%$ & $0 \%$ & $55.6 \%$ & $44.4 \%$ \\
\hline
\end{tabular}

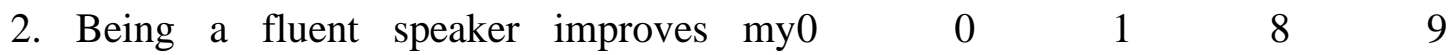

$\begin{array}{llllll}\text { knowledge and understanding. } & 0 \% & 0 \% & 5.6 \% & 44.4 \% & 50 \%\end{array}$

\begin{tabular}{|c|c|c|c|c|}
\hline $\begin{array}{l}\text { 3. It is not important for me to be fluent in } 7 \\
\text { speaking English. } \\
38.9 \%\end{array}$ & $\begin{array}{l}10 \\
55.6 \%\end{array}$ & $\begin{array}{l}0 \\
0 \%\end{array}$ & $\begin{array}{l}0 \\
0 \%\end{array}$ & $\begin{array}{l}1 \\
5.6 \%\end{array}$ \\
\hline $\begin{array}{l}\text { 4. I don't like it when teachers focus on } 8 \\
\text { improving my speaking skills. }\end{array}$ & $\begin{array}{l}6 \\
33.3 \%\end{array}$ & $\begin{array}{l}4 \\
22.2 \%\end{array}$ & $\begin{array}{l}0 \\
0 \%\end{array}$ & $\begin{array}{l}0 \\
0 \%\end{array}$ \\
\hline $\begin{array}{l}\text { 5. I would prefer the teacher to provide } \mathrm{r} \\
\text { with English speaking training so I impro }\end{array}$ & $\begin{array}{l}1 \\
5.6 \%\end{array}$ & $\begin{array}{l}1 \\
5.6 \%\end{array}$ & $\begin{array}{l}10 \\
55.6 \%\end{array}$ & $\begin{array}{l}6 \\
33.3 \%\end{array}$ \\
\hline
\end{tabular}

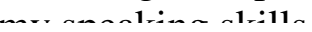

Table 1. highlights that almost all the participants believe in the importance of speaking English fluently. Most participants also preferred that teachers should focus on improving their speaking skills.

Table 2. Descriptive statistics for teachers'feedback

Questionnaire item

\begin{tabular}{ll}
$\begin{array}{l}\text { Strongly } \\
\text { disagree }\end{array}$ Disagree $_{\mathrm{n}}^{\text {Uncertai }}$ Agree & $\begin{array}{l}\text { Strongly } \\
\text { agree }\end{array}$ \\
\hline
\end{tabular}

\begin{tabular}{llllll}
\hline 6. I prefer to receive my teacher's comments 0 & 9 & 6 & 1 & 2
\end{tabular}

for my speaking tasks by email rather than $0 \% \quad 50 \% \quad 33.3 \% \quad 5.6 \% \quad 11.1 \%$

$\begin{array}{lllllll}7 . & \text { It } & \text { is more beneficial if my teacher } 2 & 2 & 2 & 2 & 10\end{array}$

comments on my speaking tasks face-to-face $11.1 \% \quad 11.1 \% \quad 11.1 \% \quad 11.1 \% \quad 55.6 \%$

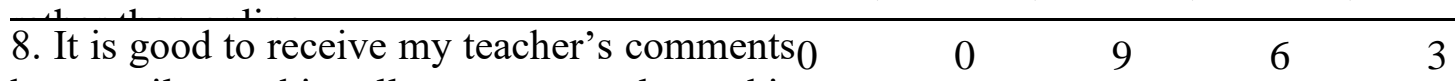

by email as this allows me to keep his $0 \% \quad 0 \% \quad 50 \% \quad 33.3 \% \quad 16.7 \%$

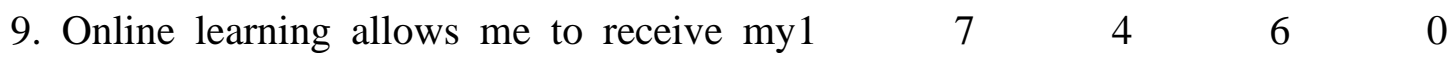

$\begin{array}{llllll}\text { teachers' comments faster. } & 5.6 \% & 38.9 \% & 22.2 \% & 33.3 \% & 0 \%\end{array}$

Participants seemed to have different views concerning receiving teachers' feedback. The majority of participants preferred to receive teachers' feedback face-to-face rather than online. 
Arab World English Journal (AWEJ) Volume 12. Number 1. March 2021

Teaching English Speaking Online versus Face-to-Face: Saudi Students'

Alzamil

However, they expressed positive attitudes towards receiving feedback by email, which allowed them to keep their teachers' comments.

Table 3. Descriptive statistics for online learning of English speaking

Questionnaire item Strongly
disagree

Strongly agree

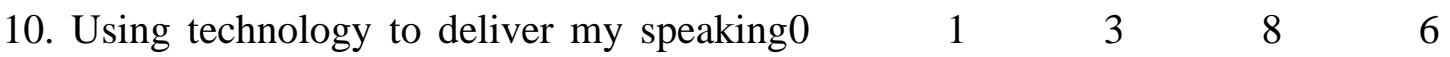
$\begin{array}{llllll}\text { tasks allows me to be a better speaker. } & 0 \% & 5.6 \% & 16.7 \% & 44.4 \% & 33.3 \%\end{array}$

\begin{tabular}{|c|c|c|c|c|c|}
\hline 1. I prefer speaking skills to be taught online & $\begin{array}{c}1 \\
5.6 \%\end{array}$ & $\begin{array}{l}4 \\
22.2 \%\end{array}$ & $\begin{array}{l}10 \\
55.6 \%\end{array}$ & $\begin{array}{l}1 \\
5.6 \%\end{array}$ & $\begin{array}{l}2 \\
11.1 \%\end{array}$ \\
\hline
\end{tabular}

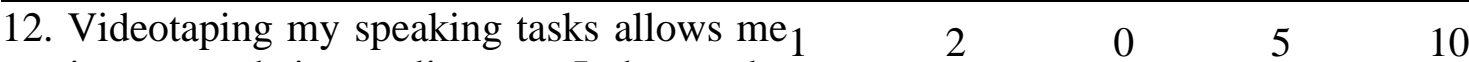
to improve their quality as I have the $5.6 \% \quad 11.1 \% \quad 0 \% \quad 27.8 \% \quad 55.6 \%$ onnortunity to reneat them if I'm not hanns

A large proportion of the participants expressed positive attitudes to using technology to deliver their speaking tasks. Yet a majority remained undecided about whether they preferred online to face-to-face learning.

Table 4. Descriptive statistics for using technology in learning

Questionnaire item Strongly
disagree ${ }_{\mathrm{n}}^{\text {Disagree }} \begin{aligned} & \text { Uncertai } \\ & \text { Agree } \\ & \text { agree }\end{aligned}$

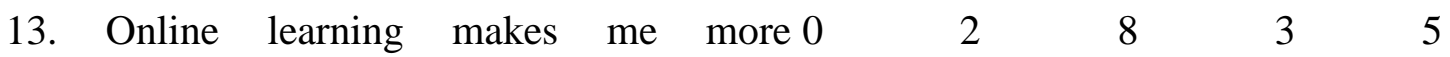
$\begin{array}{llllll}\text { independent as a learner. } & 0 \% & 11.1 \% & 44.4 \% & 16.7 \% & 27.8 \%\end{array}$

\begin{tabular}{llllll}
\hline 14. I think that teaching courses online should 6 & 6 & 1 & 3 & 4
\end{tabular} $\begin{array}{llllll}\text { continue even after the COVID-19 pandemic33.3\% } & 33.3 \% & 5.6 \% & 16.7 \% & 22.2 \%\end{array}$

\begin{tabular}{|c|c|c|c|c|c|}
\hline \multicolumn{2}{|c|}{ 15. I like the flexibility that comes with online 0} & \multirow{2}{*}{$\begin{array}{l}1 \\
5.6 \%\end{array}$} & \multirow{2}{*}{$\begin{array}{l}6 \\
33.3 \%\end{array}$} & \multirow{2}{*}{$\begin{array}{l}6 \\
33.3 \%\end{array}$} & \multirow{2}{*}{$\begin{array}{l}5 \\
27.8 \%\end{array}$} \\
\hline learning. & $0 \%$ & & & & \\
\hline \multicolumn{2}{|c|}{ 16. Face-to-face learning is more effective6 } & 5 & 2 & 3 & 4 \\
\hline than online learning. & $33.3 \%$ & $27.8 \%$ & $11.1 \%$ & $16.7 \%$ & $22.2 \%$ \\
\hline \multirow{2}{*}{\multicolumn{2}{|c|}{$\begin{array}{l}\text { 17. Online learning allows me to review0 } \\
\text { learning materials repeatedly. }\end{array}$}} & 2 & 6 & 8 & 2 \\
\hline & & $11.1 \%$ & $33.3 \%$ & $44.4 \%$ & $11.1 \%$ \\
\hline \multicolumn{2}{|c|}{ 18. Online learning is more enjoyable than 2} & 4 & 9 & 1 & 2 \\
\hline face-to-face learning. & $11.1 \%$ & $22.2 \%$ & $50 \%$ & $5.6 \%$ & $11.1 \%$ \\
\hline \multirow{2}{*}{ 19. Online learning helps students cheat. } & 2 & 5 & 0 & 8 & 3 \\
\hline & $11.1 \%$ & $27.8 \%$ & $0 \%$ & $44.4 \%$ & $16.7 \%$ \\
\hline \multirow{2}{*}{ 20. Online learning is boring. } & 3 & 4 & 6 & 3 & 2 \\
\hline & $16.7 \%$ & $22.2 \%$ & $33.3 \%$ & $16.7 \%$ & $11.1 \%$ \\
\hline \multicolumn{2}{|c|}{ 21. I look forward to online classes more than 1} & & 6 & 1 & 2 \\
\hline face cla & $5.6 \%$ & $44.4 \%$ & $33.3 \%$ & $5.6 \%$ & $11.1 \%$ \\
\hline
\end{tabular}


Participants seemed to have positive attitudes to online learning. However, when it came to the question of whether they preferred online to face-to-face learning, participants seemed to believe that online learning is less effective than face-to-face learning.

\section{Discussion}

This section is organised according to the four constructs in the questionnaire that addressed the main research questions. These were as follows: a) the importance of speaking in English; b) teachers' online feedback; c) online learning of English speaking; d) online learning of the English language.

In relation to the first construct, the participants either agreed or strongly agreed that mastering speaking was important for them. They also preferred their teachers to concentrate on improving their speaking skills. These findings support Ali et al.'s (2019) study.

With regard to the second construct, $50 \%$ of participants preferred to receive their teacher's feedback on their speaking task face-to-face rather than online. This may be because face-to-face feedback allows for discussion which is not normally the case with email. However, they appreciated the fact that receiving the feedback by email allowed them potentially to keep their teacher's comments for future use. Moreover, 33.3\% of them appreciated the speed with which they received feedback by email. Yet, neither speed nor the ability to retain email made them prefer online feedback to face-to-face feedback.

With the third construct, the majority of participants $(77.7 \%)$ felt that delivering their speaking tasks online improved their speaking skills. They (83.4\%) also thought that videotaping their speaking tasks allowed them to edit and improve their quality. However, when it came to preferring online to face-to-face teaching of English speaking, they were divided about whether they agreed or disagreed, and 55.6\% of the participants remained uncertain.

For question 1d, participants agreed or strongly agreed that online learning gave them greater independence and flexibility (44.5\% and $61.1 \%$ respectively). However, a majority $(66.6 \%)$ opposed the continuation of online learning after the pandemic ends, as most $(61.1 \%)$ believe that face-to-face learning is superior to online learning. However, they were not as opposed, as discussed earlier, to statement 11, 'I prefer speaking skills to be taught online', where their views were split. It could be that their experience with regard to learning speaking online was different from their experience on other courses: for example, only $16.7 \%$ of participants looked forward to online classes whereas $60 \%$ looked forward to face-to-face learning. Many (61.1\%) even reported that online learning facilitates students' cheating. Participants were divided about whether online learning is boring, expressing views that ranged from strongly disagree to strongly agree. This can be explained by remembering that some students tend to consider all learning, of whatever type, boring.

The findings above support the findings by Paechter and Maier (2010) and Gorra and Bhati (2016) to the extent that the participants believe that online learning has its benefits and roles in L2 learning. However, the findings of the present study failed to show that participants preferred online over face-to-face learning altogether, as did the participants in, for example, Fansury et al.'s (2020) study. 


\section{Conclusion}

This study was limited to a small number of participants because the COVID-19 pandemic meant that some potential participants could not be reached. It addressed the attitudes of university-level Saudi students towards: a) the importance of speaking English; and) distance learning and teaching English speaking. Participants had positive views towards the use of distance learning and teaching and learning English. The findings showed that the participants: a) had positive attitudes to the importance of speaking English, and b) appreciated the benefits that online learning offers. Participants did not believe it could replace face-to-face learning.

These results are interesting, in spite of the study's limitations in terms of the small number of participants. A larger study is needed to determine whether its outcomes can be reliably replicated.

\section{About the Author:}

Dr. Abdulrahman Alzamil is an associate professor of second language acquisition of syntax in the Department of Foreign Languages at Taif University in Saudi Arabia. His research interests lie primarily in the area of generative second language acquisition of morphosyntactic and semantic properties. ORCiD: https://orcid.org/0000-0003-2462-3408

\section{References}

Al-Ahdal, A., Alfallaj, F., Al-Awaied, S., \& Al-Hattami, A. (2014). A comparative study of proficiency in speaking and writing among EFL learners in Saudi Arabia. American International Journal of Contemporary Research, 4(2), 141-149.

Al-Asmari, A. M., \& Khan, M. S. R. (2014). E-learning in Saudi Arabia: Past, present and future. Near and Middle Eastern Journal of Research in Education, (1), 1-11. https://doi.org/10.5339/nmejre.2014.2

Alhabeeb, A., \& Rowley, J. (2017). Critical success factors for eLearning in Saudi Arabian universities. International Journal of Educational Management, 31(2), 131-147. https://doi.org/10.1108/IJEM-01-2016-0006

Alharbi, H. A. (2015). Improving Students' English Speaking Proficiency in Saudi Public Schools. International Journal of Instruction, 8(1), 105-116. https://doi.org/10.12973/iji.2015.818a

Alhmadi, N. S. (2014). English speaking learning barriers in Saudi Arabia: A case study of Tibah University. Arab World English Journal, 5(2), 38-53.

Ali, J. K. M., Shamsan, M. A., Guduru, R., \& Yemmela, N. (2019). Attitudes of Saudi EFL learners towards speaking skills. Arab World English Journal, 10(2), 253-264. https://dx.doi.org/10.24093/awej/vol10no2.27

Alsaedi, A. (2012). The teaching of EFL speaking in developed secondary public schools for females in Saudi Arabia: A case study, (Unpublished doctoral dissertation). University of Southampton, Southampton, UK.

Carbonilla Gorra, V., \& Bhati, S. S. (2016). Students' perception on use of technology in the classroom at higher education institutions in Philippines. Asian Journal of Education and $e$ Learning, 4(3), 92-103.

Fansury, A. H., Januarty, R., \& Ali Wira Rahman, S. (2020). Digital Content for Millennial Generations: Teaching the English Foreign Language Learner on COVID-19 Pandemic. 
Journal of Southwest Jiaotong University, 55(3), 1-12. https://doi.org/10.35741/issn.02582724.55.3.40

Fulcher, G. (2003). Testing Second Language Speaking. Harlow: Pearson Education.

Hamad, M. M. (2013). Factors Negatively Affect Speaking Skills at Saudi Colleges for Girls in the South. English Language Teaching, 6(12), 87-97. https://doi.org/10.5539/elt.v6n12p87

Harandi, S. R. (2015). Effects of e-learning on students' motivation. Procedia-Social and Behavioral Sciences, 181, 423-430. https://doi.org/10.1016/j.sbspro.2015.04.905

Larson-Hall, J. (2016). A Guide to Doing Statistics in Second Language Research Using SPSS and $R$. New York: Routledge. https://doi.org/10.4324/9781315775661

Paechter, M., \& Maier, B. (2010). Online or face-to-face? Students' experiences and preferences in e-learning. The internet and higher education, 13(4), 292-297. https://doi.org/10.1016/j.iheduc.2010.09.004

Sharma, V. K. (2015). How do productive skills of Saudi students affect EFL learning and teaching. Asian Journal of Humanities and Social Sciences (AJHSS), 3(2), 91-99. 